http://kitaibelia.unideb.hu/

ISSN 2064-4507 (Online) • ISSN 1219-9672 (Print)

(C) 2015, Department of Botany, University of Debrecen, Hungary

21 (1): 16-26.; 2016

DOI: $10.17542 /$ kit.21.16

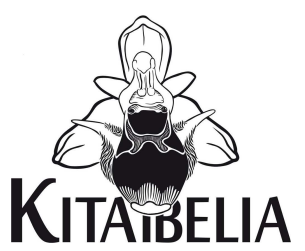

\title{
Adatok a Mecsek hegység zuzmóflórájához
}

\author{
KovÁcs Dániel ${ }^{1}$ \& LőKÖS László ${ }^{2}$
}

(1) Pécsi Tudományegyetem, Ökológiai Tanszék, H-7624 Pécs, Ifjúság útja 6.; *dancs12@msn.com

(2) MTM Növénytár, H-1431 Budapest, Pf. 137.

\section{Contributions to the lichen flora of the Mecsek Mts (South Hungary)}

\begin{abstract}
A checklist of 115 lichen taxa was compiled from the Mecsek Mts, based on floristical records of 221 old or recently collected herbarium specimens (incl. 37 duplicates) deposited in the JPU herbarium (Pécs, Hungary). The occurrence of 22 taxa are new for the Mecsek Mts: Arthopyrenia cinereopruinosa, Baeomyces rufus, Candelariella reflexa, Catapyrenium rufescens, Cladonia macilenta, Dimerella pineti, Hypogymnia tubulosa, Ochrolechia arborea, Pleurosticta acetabulum, Pseudevernia furfuracea, Psilolechia lucida, Pycnothelia papillaria, Rinodina sophodes, Tomasellia arthonioides, Toninia candida, Trapelia involuta, Varicellaria hemisphaerica, Verrucaria marmorea, $V$. nigrescens, $V$. parmigera, Xanthoparmelia conspersa, X. verruculifera. One legally protected lichen species (Peltigera leucophlebia) is also represented by two specimens.
\end{abstract}

Keywords: Ferenc Fóriss, floristics, Hungary, lichen-forming fungi, Móric Majer, Ochrolechia

Összefoglalás - A Pécsi Tudományegyetem (JPU) zuzmógyűjteményében lévő részben korábbi, részben saját gyưjtések alapján 115 zuzmótaxon 221, eddig nem publikált mecseki adatát közöljük, beleértve 37 JPU duplumot is. A feldolgozás eredményeként 22 új fajt mutattunk ki a hegység területéről: Arthopyrenia cinereopruinosa, Baeomyces rufus, Candelariella reflexa, Catapyrenium rufescens, Cladonia macilenta, Dimerella pineti, Hypogymnia tubulosa, Ochrolechia arborea, Pleurosticta acetabulum, Pseudevernia furfuracea, Psilolechia lucida, Pycnothelia papillaria, Rinodina sophodes, Tomasellia arthonioides, Toninia candida, Trapelia involuta, Varicellaria hemisphaerica, Verrucaria marmorea, V. nigrescens, V. parmigera, Xanthoparmelia conspersa, X. verruculifera. A törvényesen védett Peltigera leucophlebia két adattal szerepel a listában.

Kulcsszavak: florisztika, Fóriss Ferenc, Magyarország, Majer Móric, Ochrolechia, zuzmóképző gombák

\section{Bevezető}

A Dél-Dunántúl, ezen belül is a Mecsek és környéke zuzmóflorisztikai szempontból meglehetősen alulkutatottnak számít. Jelentősebb lichenológiai gyűjtő- és feltáró munkát Boros Ádám, Fóriss Ferenc és Kőfaragó-Gyelnik Vilmos végzett a Mecsek területén zömében még a múlt század első felében (LőKös 2010), míg a század második felében inkább a Barcsi Ősborókásban (GALLÉ 1978, THOR 1988) és a Villányi-hegységben (LőKÖS 2000, MARSTALLER 1993, VERSEGHY 1973) történtek kutatások. Az elmúlt évtizedben csupán két helyen (Ibafa, Cserkút), egy-egy napon került sor jelentősebb gyűjtőmunkára. Mindkét alkalom a Magyar Biodiverzitás Napok programsorozathoz kapcsolódott (FARKAS \& LőKÖS 2009; VARGA et al. 2014). Ezen lokális fajlisták alapján azonban nem kaphatunk átfogó képet a térség zuzmóflórájáról. 
A Mecsek zuzmóflórájának alapvetésében összegyűjtésre kerültek a területhez kapcsolódó irodalmi és herbáriumi adatok (LőКӧs 2010). Az enumerációban összegzett 191 faj kilenc herbárium mintegy 550 példányának adatain alapul, amelyek főként a BP és az EGR, illetve 14 példány esetében a Pécsi Tudományegyetem (JPU) (Majer Móric anyaga) gyüjteményéből származnak.

A közelmúltban kerültek digitalizálásra a Pécsi Tudományegyetem herbáriumában (JPU) található zuzmógyűjtemények (Kovács 2015). A JPU részgyűjteményei közül négyben találhatók zuzmók (összesen 3072 rekord). Egy-egy a Mecsekből származó példány a Pannonhalmi Gyüjteményben, illetve Nendtvich Vilmos herbáriumában is fellelhető. Ennél több adatot tartalmaz a Majer Móric-féle „Baranyai virány”, míg a legtöbb hegységbeli gyűjtés a törzsgyűjteményben található. Ennek gerincét Fóriss Ferenc példányai alkotják, melyek jelentős része duplum. Az adatbázist leszűrve több, eddig ismeretlen előfordulásra leltünk, annak ellenére, hogy a mecseki gyüjtések JPU-beli aránya alacsony, mindössze hét százalék. A zuzmókollekció az elmúlt 50 évben nem bővült, de 2014-től folyamatos a gyarapodása. Mindemellett a JPU régi Bacidia, Cetrelia, Cladonia és Xanthoparmelia példányai egy részének modern, kémiai alapú revíziója is megtörtént, melynek publikálása folyamatban van.

Jelen írásunkban a fentebb említett, eddig ismeretlen régi mecseki adatokat (113 rekord) és az újonnan gyüjtött mintáink egy részét (108 rekord) adjuk közre.

\section{Anyag és módszer}

A törzsgyűjtemény példányai a leltárba vételkor nem lettek újraszámozva, így Fóriss Ferenc gyűjtôszámai egyben a példányok azonosítószámait is jelentik. A JPU gyüjteményben 31924 a legnagyobb Fóriss-féle gyújtőszám, Fóriss naplói szerint 31968-ig gyűjtött, így úgy döntöttünk, hogy a következő kerek számmal, 32 000-rel kezdődően kapnak azonosítószámot az új példányok. A Majer Móric-féle herbárium kis, könyvszerü tartókban van, ezek római számokkal vannak ellátva 1-től 18-ig. A tartókon belül a lapok arab számokkal vannak jelölve, minden egyes könyvecske esetében egytől kezdődően. A számozás azonban redundáns, egy lapon szerepelhet több faj is, illetve több lapnak lehet ugyanaz a száma, ha azonosnak vélt taxonok vannak rájuk ragasztva. Zuzmókat csak az utolsó tartó tartalmaz. A Pannonhalmi Gyüjtemény zuzmói nem rendelkeznek egységes számozással. A lelőhelyi adatok minősége heterogén képet mutat. A régebbi példányok esetében a gyűjtés helye sokszor csak településrész szintjén beazonosítható, míg Majer Móric gyűjteményében csak a településnév szerepel. Ezzel szemben az új gyüjtések esetében minden példányon feltüntetésre kerülnek a földrajzi koordináták is.

Mint már említettük a Fóriss-féle anyagban jelentős a duplumok száma. Ezek egy részét, mint mecseki előfordulásokat, az MTM növénytári (BP-beli) példányok alapján LőKös (2010) már közölte, ám indokoltnak tartjuk e gyüjtések JPU-ban található duplumainak publikálását is. Ezen eseteket a leltári számot követő „(D)”-vel jelöltük.

Az enumerációban a taxonokat tudományos nevük alapján ábécérendben soroljuk fel. Az aktuális taxonnevek tekintetében elsősorban az IndexFungorum (CABI 2015) adatbázisára támaszkodtunk. A cédulákon szereplő lelőhelyi adatokat helytakarékossági okokból rövidítve közöljük, a gondolatjelekkel ábécérendben különválasztott településeken belül, a szintén alfabetikusan rendezett földrajzi egységeket pontosvesszők tagolják. Majd, a saját gyűjtések esetén, a földrajzi koordináták következnek decimális formátumban („É.sz.:” = északi szélesség, „K.h.:” = keleti hosszúság). A földrajzi nevek esetében a Mecsek 1:40 000es méretarányú turistatérképéhez (MVhT 2013) igazodtunk. A Substr. rövidítést követően kerül részletezésre az aljzat minősége, a következő rövidítésekkel (Fóriss szóhasználatára alapozva): aren. = arenaceus (homok); arg. = argillosus (agyagos); cort. = cortex (kéreg); 
putr. = putridus (korhadt); calc. = calcareus (meszes); dolom. = dolomiticus (dolomit); musc. $=$ muscosus (mohás); lign. = lignum (faanyag); sicc. = siccus (száraz); trunc. = truncus (fatörzs); vetust. = vetustus (régi, idős). A gyűjtési adatokat a „Leg.” rövidítéssel kezdődően részletezzük (gyűjtő neve, gyújtés időpontja, a példány azonosítószáma). A „sub” a szinonimként tekintett vagy a tévesen alkalmazott neveket jelöli. Az új gyüjtések határozását, illetve a régi anyagok revideálását a szerzők végezték, ezért az enumerációban nem tüntetjük fel ezen adatokat. A Mecsek hegységre új fajokat csillaggal (*) emeltük ki a listában.

A florisztikai adatok az alábbi gyűjtőktől származnak: Balanyi László, Csiky János, Deme Judit, Fóriss Ferenc, (Kőfaragó-)Gyelnik Vilmos, Kovács Dániel és Majer Móric.

\section{Enumeráció}

Acarospora cervina (Ach.) A. Massal. - Pécs: Mecsek szálló. Substr.: saxa calc. Leg. Fóriss F., 1955.07.06. (JPU 27762 (D), sub f. pruinosa). [FóRISS 1957].

Acarospora fuscata (Nyl.) Th. Fr. - Kővágószőlős: Babás-szerkövek. É.sz.: 46,092209º K.h.: 18,129004 . Substr.: saxa aren. Leg. Kovács D., 2014.11.07. (JPU 32056).

Acrocordia gemmata (Ach.) A. Massal. - Pécs: Közép-Daindol felett. É.sz.: 46,099872 ${ }^{\circ}$ K.h.: 18,201679. Substr.: cort. Querci. Leg. Kovács D., 2015.03.20. (JPU 32145).

Amandinea punctata (Hoffm.) Coppins et Scheid. - Abaliget: vasútállomás. É.sz.: 46,153758 ${ }^{\circ}$, K.h.: 18,073388 . Substr.: cort. Alni. Leg. Kovács D., 2014.12.19. (JPU 32023). Pécs: Misina. Substr.: cort. Laricis. Leg. Fóriss. F., 1955.07.03. (JPU 27419 (D), sub Buellia p. f. punctiformis; JPU 27428 (D), sub Buellia p. var. chloroleuca).

*Arthopyrenia cinereopruinosa (Schaer.) A. Massal. - Inter Pécs et Pécsvárad. Substr.: cort. Mori. Leg. Gyelnik V., 1925.08.03. (JPU 29451).

Aspicilia cinerea (L.) Körb. - Pécs: Turistaházak. Substr.: saxa aren. Leg. Fóriss F., 1955.07.03. (JPU 27504).

Aspicilia contorta (Hoffm.) Körb. subsp. hoffmanniana R. Sant. - Pécs: Dömörkapu. Substr.: saxa calc. Leg. Fóriss F., 1955.07.02. (JPU 27352, sub A. hoffmannii).

Aspicilia intermutans (Nyl.) Arnold - Kővágószőlős: Jakab-hegyi kilátó. Substr.: saxa aren. Leg. Fóriss F., 1955.07.05. (JPU 27681, sub A. reticulata var. ammotropha; JPU 27687 (D), sub $A$. reticulata var. intermutans).

Athallia holocarpa (Hoffm.) Arup, Frödén et Søchting - Pécs: Mecsek szálló. Substr.: saxa dolom. Leg. Fóriss F., 1955.07.06. (JPU 27744, sub C. pyracea var. rupestris).

Bacidia bagliettoana (A. Massal. et De Not.) Jatta - Pécs: Tubes, Lapisi út. É.sz.: 46,105773º, K.h.: 18,199581․ Substr.: terra musc. Leg. Kovács D., 2015.03.20. (JPU 32142).

Bacidia rubella (Hoffm.) A. Massal. - Pécs: Tubes, Lapisi út. É.sz.: 46,103782º K.h.: 18,201149. Substr.: cort. Querci. Leg. Kovács D., 2015.03.20. (JPU 32104).

*Baeomyces rufus (Huds.) Rebent. - Pécs: Misina, sípálya alja. É.sz.: 46,105754 ${ }^{\circ}$ K.h.: 18,223802 ${ }^{\circ}$. Substr.: terra arg. Leg. Kovács D., 2014.05.02. (JPU 32084).

Bilimbia sabuletorum (Schreb.) Arnold - Pécs: Tubes, Lapisi út. É.sz.: 46,105773ㅇ, K.h.: 18,199581․ Substr.: terra musc. Leg. Kovács D., 2015.03.20. (JPU 32107; JPU 32141).

Buellia disciformis (Fr.) Mudd - Pécs: Kantavári erdőőri ház. Substr.: cort. Fagi. Leg. Fóriss F., 1955.07.03. (JPU 27518 (D)); Misina. Substr.: cort. Fagi. Leg. Fóriss F., 1955.07.03. (JPU 27453, sub var. rugulosa).

Caloplaca chalybaea (Fr.) Müll. Arg. - Pécs: Mecsek szálló. Substr.: saxa calc. Leg. Fóriss F., 1955.07.06. (JPU 27736 (D), sub Pyrenodesmia ch.).

Caloplaca variabilis (Pers.) Müll. Arg. - Pécs: Irma út, Lenkei pihenő. Substr.: saxa calc. Leg. Fóriss F., 1955.07.02. (JPU 27389, sub Pyrenodesmia v. f. densa).

Candelariella aurella (Hoffm.) Zahlbr. - Pécs: Mecsek szálló. Substr.: saxa calc. Leg. Fóriss F., 1955.07.06. (JPU 27765, sub var. aurella). 
*Candelariella reflexa (Nyl.) Lettau - Pécs: Kis-Tubes, kilátó. É.sz.: 46,102908, K.h.: 18,207914. Substr.: cort. Fraxini orni. Leg. Kovács D., 2015.03.20. (JPU 32099).

Candelariella xanthostigma (Ach.) Lettau - Pécs: Bányatelep. Substr.: cort. Pyri comm. Leg. Fóriss F., 1955.07.03. (JPU 27467).

*Catapyrenium rufescens (Ach.) Breuss - Pécs: Dömörkapu, Flóra pihenő. É.sz.: 46,099241 K.h.: 18,234032․ Substr.: saxa calc. Leg. Deme J., 2015.03.21. (JPU 32087).

Circinaria calcarea (L.) Nordin, Savić et Tibell - Pécs: Dömörkapu. Substr.: saxa calc. Leg. Fóriss F., 1955.07.02. (JPU 27353; JPU 27358, sub Pachyospora calcarea f. atomaria); Irma út, Lenkei pihenő. Substr.: saxa calc. Leg. Fóriss F., 1955.07.02. (JPU 27394, sub Pachyospora caesioalba).

Cladonia bacillaris (Ach.) Genth - Pécs: Magyarürög, Jakab-hegy. Leg. Substr.: trunc. vetust. Querci. Fóriss F., 1955.07.05. (JPU 27608 (D), sub f. tenuistipata); Misina. Substr.: trunc. vetust. Querci. Leg. Fóriss F., 1955.07.03. (JPU 27466).

Cladonia chlorophaea (Sommerf.) Spreng. - Pécs: Éger-völgy. É.sz.: 46,096176 ${ }^{\circ}$ K.h.: 18,172693 és É.sz.: 46,091535, K.h.: 18,178371. Substr.: cort. Querci et terra arg. Leg. Kovács D. 2015.02.21. (JPU 32009), 2015.03.07. (JPU 32090; JPU 32126).

Cladonia convoluta (Lam.) Anders - Pécs. Leg. Majer M., 1860. (JPU XVIII/74, sub C. endiviaefolia); Mecsek szálló. Substr.: terra humosa. Leg. Fóriss F., 1955.07.06. (JPU 27723 (D), sub C. foliacea var. convoluta).

Cladonia fimbriata (L.) Fr. - Abaliget: vasútállomás, a lucosban. É.sz.: 46,150901, K.h.: 18,078157. Substr.: cort. Picea abies. Leg. Kovács D., 2014.12.19. (JPU 32019). - Pécs. Leg. Majer M., 1860. (JPU XVIII/66, sub C. cervicornis); Magyarürög, Jakab-hegy. Substr.: terra arg. Leg. Fóriss F., 1955.07.05. (JPU 27579 (D); JPU 27580, sub C. major); Quinque Ecclesiis in nemorosis montis Mecsek. Leg. ?, 1844.09. (Pannonhalmi gyüjtemény, s. n., sub Cenomyce pyxidata).

Cladonia furcata (Huds.) Schrad. - Pécs: Éger-völgy. É.sz.: 46,078157º, K.h.: 18,177999. Substr.: terra arg. Leg. Kovács D., 2015.02.21. (JPU 32010).

Cladonia gracilis (L.) Willd. - Pécs. Leg. Majer M., 1860. (JPU XVIII/66, sub C. cervicornis).

*Cladonia macilenta Hoffm. - Pécs: Éger-völgy. É.sz.: 46,091535, K.h.: 18,178371 . Substr.: putr. Querci. Leg. Kovács D., 2015.03.07. (JPU 32137).

Cladonia parasitica (Hoffm.) Hoffm. - Pécs: Magyarürög, Jakab-hegy. Substr.: trunc. vetust. Querci. Leg. Fóriss F., 1955.07.05. (JPU 27607 (D), sub C. delicata f. quercina).

Cladonia rangiformis Hoffm. - Pécs: Éger-völgy. É.sz.: 46,091034 ${ }^{\circ}$ K.h.: 18,178447º Substr.: talajon. Leg. Deme J., 2015.02.27. (JPU 32114).

Cladonia squamosa (Scop.) Hoffm. - Kővágószőlős: Babás-szerkövek. É.sz.: 46,092854º K.h.: 18,128748 ${ }^{\circ}$ Substr.: terra arg. Leg. Kovács D., 2014.11.07. (JPU 32060); Jakab-hegy, Zsongor-kő alatt. É.sz.: 46,092514, K.h.: 18,137816². Substr.: terra arg. Leg. Kovács D., 2014.04.12. (JPU 32072), 2014.11.25. (JPU 32046).

Cladonia subulata (L.) F. H. Wigg. - Pécs: Magyarürög, Jakab-hegy. Substr.: terra arg. Leg. Fóriss F., 1955.07.05. (JPU 27581 (D), sub C. cornuto-radiata var. subulata).

Cladonia uncialis (L.) F. H. Wigg. - Pécs. Leg. Majer M., 1860. (JPU XVIII/72, sub C. stellata var. turgescens).

Dermatocarpon miniatum (L.) W. Mann - Pécs: Tubes, Lapisi út. É.sz.: 46,103782 ${ }^{\circ}$ K.h.: 18,201149. Substr.: saxa dolom. Leg. Kovács D., 2015.03.20. (JPU 32133).

Dibaeis baeomyces (L. f.) Rambold et Hertel - Pécs: Éger-völgy és a Mohosi-kis-kút völgyének találkozásánál. É.sz.: 46,092477º, K.h.: 18,174324º. Substr.: terra arg. Leg. Kovács D., 2014.10.18. (JPU 32079); Misina, sípálya alja. É.sz.: 46,105754 ${ }^{\circ}$ K.h.: 18,223802 ${ }^{\circ}$. Substr.: terra arg. Leg. Kovács D., 2014.05.02. (JPU 32082; JPU 32083; JPU 32084); Pécs-Vasas, a Liget utcától D-re lévő hegyen. É.sz.: 46,134141 , K.h.: 18,316450. Substr.: terra arg. Leg. Kovács D., 2015.03.27. (JPU 32105); Pécs-Vasas, Kopasz-óvár. É.sz.: 
46,141188 ${ }^{\circ}$, K.h.: 18,311531 ${ }^{\circ}$ Substr.: terra arg. Leg. Kovács D., 2015.04.02. (JPU 32106; JPU 32108).

*Dimerella pineti (Ach.) Vězda - Pécs: Éger-völgy és a Mohosi-kis-kút völgyének találkozásánál. É.sz.: 46,092477º, K.h.: 18,174324. Substr.: terra arg. Leg. Kovács D., 2014.10.18. (JPU 32000). - A faj jellemzően fakérgen él, de ritkábban növényi korhadékon, mohos talajon is előfordulhat.

Diploschistes scruposus (Schreb.) Norman - Inter Kárász et Vékény. Substr.: trachydolericola. Leg. Kőfaragó-Gyelnik V., 1937.09.04. (JPU 23855, sub f. vulgaris). Kővágószőlős: Jakab-hegy, kilátó. Substr.: saxa aren. Leg. Fóriss F., 1955.07.05. (JPU 27696, sub var. octospora).

Diplotomma ambiguum (Ach.) Flagey - Pécs: Magyarürög, Jakab-hegy. Substr.: saxa aren. Leg. Fóriss F., 1955.07.05. (JPU 27646 (D)).

Diplotomma epipolium (Ach.) Arnold - Pécs: Mecsek szálló. Substr.: saxa calc. Leg. Fóriss F., 1955.07.06. (JPU 27753, sub var. murorum).

Evernia prunastri (L.) Ach. - Abaliget: vasútállomás. É.sz.: 46,156156º K.h.: 18,073849º és É.sz.: 46,155479 , K.h.: 18,075057 . Substr.: cort. Leg. Kovács D., 2014.12.19. (JPU 32040; JPU 32051). - Kővágószőlős: Babás-szerkövek. É.sz.: 46,092209º K.h.: 18,129004 . Substr.: cort. Querci. Leg. Kovács D., 2014.11.07. (JPU 32058). - Pécs: Magyarürög, Jakab-hegy. Substr.: cort. Fagi. Leg. Fóriss F., 1955.07.05. (JPU 27597 (D), sub var. sorediifera).

Flavoparmelia caperata (L.) Hale - Abaliget: vasútállomás. É.sz.: 46,154771º, K.h.: 18,077902 ${ }^{\circ}$. Substr.: cort. Pruni cerasifera. Leg. Kovács D., 2014.12.19. (JPU 32050). - Pécs: Éger-völgy. É.sz.: 46,089413º, K.h.: 18,179470. Substr.: cort. Alni. Leg. Kovács D., 2015.02.21. (JPU 32011).

Gyalolechia flavovirescens (Wulfen) Søchting, Frödén et Arup - Pécs: Kis-Tubes, kilátó. É.sz.: 46,102908 ${ }^{\circ}$ K.h.: 18,207914 ${ }^{\circ}$ Substr.: saxa dolom. Leg. Kovács D., 2015.03.20. (JPU 32095).

Hypogymnia physodes (L.) Nyl. - Abaliget: a vasútállomásnál és a lucosban. É.sz.:

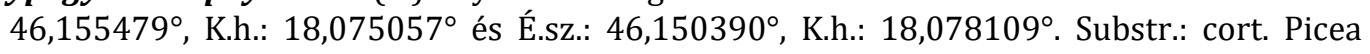
abies et Querci. Leg. Kovács D., 2014.12.19. (JPU 32013; JPU 32020; JPU 32052). Kővágószőlős: Babás-szerkövek. É.sz.: 46,092854º K.h.: 18,128748 . Substr.: cort. Querci. Leg. Kovács D., 2014.11.07. (JPU 32066). - Pécs. Leg. Majer M., 1860. (JPU XVIII/89, sub Imbricaria ceratophylla; JPU XVIII/92, sub Imbricaria physodes var. ceratophylla).

*Hypogymnia tubulosa (Schaer.) Hav. - Abaliget: vasútállomás és a lucosban. É.sz.:

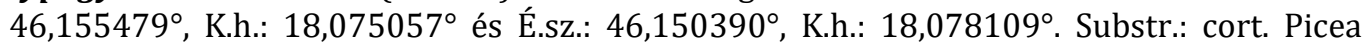
abies et Pinus. Leg. Kovács D., 2014.12.19. (JPU 32015; JPU 32014). - Kővágószőlős: Babás-

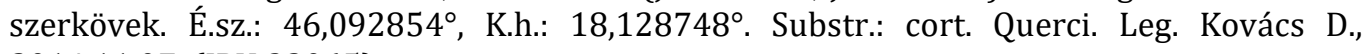
2014.11.07. (JPU 32065).

Lasallia pustulata (L.) Mérat - Bakonya: Farkas-tető. É.sz.: 46,102273, K.h.: 18,088697. Substr.: saxa aren. Leg. Csiky J. et Kovács D., 2015.04.24. (JPU 32055). - Kővágószőlős: Jakab-hegy, Sasfészektôl ÉNy-ra. É.sz.: 46,09607º K.h.: 18,12985. Substr.: saxa aren. Leg. Kovács D., 2014.11.07. (JPU 32068).

Lecanora allophana (Ach.) Nyl. - Pécs: Magyarürög, in vinetis. Substr.: cort. Juglandis. Leg. Fóriss F., 1955.07.05. (JPU 27537 (D)); Magyarürög, Jakab-hegy. Substr.: cort. Carpini. Leg. Fóriss F., 1955.07.05. (JPU 27585, sub L. rugosa).

Lecanora carpinea (L.) Vain. - Abaliget: vasútállomás. É.sz.: 46,154068 ${ }^{\circ}$ K.h.: 18,077888. Substr.: cort. Acer pseudoplatanus. Leg. Kovács D., 2014.12.19. (JPU 32039). - Pécs: Inter Bányatelep et Turistaház. Substr.: cort. Querci. Leg. Fóriss F., 1955.07.03. (JPU 27496, sub var. cinerella); Magyarürög, Jakab-hegy. Substr.: cort. Querci. Leg. Fóriss F., 1955.07.05. (JPU 27571 (D)). 
Lecanora dispersa (Pers.) Röhl. - Pécs: Irma út, Lenkei pihenő. Substr.: saxa calc. Leg. Fóriss F., 1955.07.02. (JPU 27391).

Lecidea fuscoatra (L.) Ach. - Kővágószőlős: Jakab-hegyi kilátó. Substr.: saxa aren. Leg. Fóriss F., 1955.07.05. (JPU 27684 (D), sub f. fuscoatra).

Lecidella elaeochroma (Ach.) M. Choisy - Abaliget: vasútállomás. É.sz.: 46,153758º, K.h.: 18,073388 ${ }^{\circ}$. Substr.: cort. Alni et Cornus sanguineus. Leg. Kovács D., 2014.12.19. (JPU 32024; JPU 32053). - Pécs: Kantavár. Substr.: cort. Fagi. Leg. Fóriss F., 1955.07.03. (JPU 27524, sub L. glomerulosa); Magyarürög, in vinetis. Substr.: cort. Juglandis. Leg. Fóriss F., 1955.07.05. (JPU 27542 (D), sub L. glomerulosa f. granulosa); Misina. Substr.: cort. Fagi. Leg. Fóriss F., 1955.07.03. (JPU 27451, sub L. glomerulosa f. achrista).

Lecidella stigmatea (Ach.) Hertel et Leuckert - Pécs: Irma út, Hamedli emlékmú. Substr.: saxa calc. Leg. Fóriss F., 1955.07.04. (JPU 27373, sub Lecidea vulgata var. pilularis f. lurida).

Leptorhaphis amygdali (A. Massal.) Zwackh - Pécs: Tettye. Substr.: cort. Pruni amyg. Leg. Fóriss F., 1955.07.02. (JPU 27403 (D), sub L. parameca f. amygdali).

Melanelia subaurifera (Nyl.) Essl. - Pécs: Éger-völgy. É.sz.: 46,091535, K.h.: 18,178371². Substr.: cort. Querci. Leg. Kovács D., 2015.03.07. (JPU 32144).

Melanelixia glabratula (Lamy) Sandler et Arup - Kővágószőlős: Jakab-hegy, Babásszerkövek Ny-i végén. É.sz.: 46,092854ํㅜ, K.h.: 18,128748². Substr.: cort. Querci. Leg. Kovács D., 2014.11.07. (JPU 32057); Jakab-hegy, Zsongor-kő alatt. É.sz.: 46,091580º K.h.: 18,139470 ${ }^{\circ}$. Substr.: cort. Querci. Leg. Kovács D., 2014.04.12. (JPU 32076). - Pécs: Égervölgy. É.sz.: 46,091535 ${ }^{\circ}$ K.h.: 18,178371ํ. Substr.: cort. Querci. Leg. Kovács D., 2015.03.07. (JPU 32143); Inter Pécs-Bányatelep et Turistaház. Substr.: cort. Querci. Leg. Fóriss F., 1955.07.03. (JPU 27498, sub Parmelia fuliginosa var. laetevirens); Kantavár, erdőőri ház. Substr.: cort. Querci. Leg. Fóriss F., 1955.07.03. (JPU 27519, sub Parmelia fuliginosa var. g.); Magyarürög, Jakab-hegy. Substr.: cort. Querci. Leg. Fóriss F., 1955.07.05. (JPU 27559, sub Parmelia fuliginosa; JPU 27569, sub Parmelia fuliginosa var. laetevirens f. robustior).

Melanohalea elegantula (Zahlbr.) O. Blanco, A. Crespo, Divakar, Essl., D. Hawksw. et Lumbsch - Pécs: Magyarürög, Jakab-hegy. Substr.: cort. Aesculi. Leg. Fóriss F., 1955.07.05. (JPU 27623, sub Parmelia e.).

Melanohalea exasperatula (Nyl.) 0. Blanco, A. Crespo, Divakar, Essl., D. Hawksw. et Lumbsch - Pécs: Inter Turistaház et Kantavári Kisrét. Substr.: cort. Querci. Leg. Fóriss F., 1955.07.03. (JPU 27511, sub Parmelia e.).

Moelleropsis nebulosa (Hoffm.) Gyeln. - Pécs: Magyarürög, Jakab-hegy. Substr.: terra. Leg. Fóriss F., 1955.07.05. (JPU 27558 (D), sub Pannaria n.).

*Ochrolechia arborea (Kreyer) Almb. - Kővágószőlős: Jakab-hegy, Sasfészektől ÉNy-ra. É.sz.: 46,09607 , K.h.: 18,12985 . Substr.: cort. Querci. Leg. Kovács D., 2014.11.07. (JPU 32064). - A negyedik hazai, irodalmi adata, legközelebb a zselici Ibafán találták (vö. FARKAS et al. 2009).

Parmelia glabra (Schaer.) Nyl. - Pécs. Leg. Majer M., 1860. (JPU XVIII/85, sub P. olivacea); Dömörkapu. Substr.: cort. Querci. Leg. Fóriss F., 1955.07.02. (JPU 27358).

Parmelia saxatilis (L.) Ach. - Kővágószőlős: Babás-szerkövek. É.sz.: 46,092854, K.h.: 18,128748 ${ }^{\circ}$. Substr.: saxa aren. Leg. Kovács D., 2014.11.07. (JPU 32062); Jakab-hegy, Zsongor-kő alatt. É.sz.: 46,091486 ${ }^{\circ}$ K.h.: 18,139943․ Substr.: cort. Querci. Leg. Kovács D., 2014.11.25. (JPU 32045).

Parmelia sulcata Taylor - Pécs. Leg. Majer M., 1860. (JPU XVIII/89, sub Imbricaria ceratophylla); Magyarürög, Jakab-hegy. Substr.: terra arg. musc. Leg. Fóriss F., 1955.07.05. (JPU 27719).

Parmelina quercina (Willd.) Hale - Pécs: Magyarürög, Jakab-hegy. Substr.: cort. Querci. Leg. Fóriss F., 1955.07.05. (JPU 27560 (D)). 
Parmelina tiliacea (Hoffm.) Hale - Pécs: Közép-Daindol. É.sz.: 46,103069 K.h.: 18,200242. Substr.: cort. Querci. Leg. Kovács D., 2015.03.20. (JPU 32100); Magyarürög, Jakab-hegy. Substr.: cort. Fagi. Leg. Fóriss F., 1955.07.05. (JPU 27600, sub P. scortea).

Parmeliopsis ambigua (Wulfen) Nyl. - Pécs: Éger-völgy. É.sz.: 46,091535, K.h.: 18,178371². Substr.: putr. Querci. Leg. Kovács D., 2015.03.07. (JPU 32098).

Parmotrema perlatum (Huds.) M. Choisy - Pécs. Leg. Majer M., 1860. (JPU XVIII/90, sub Imbricaria perlata; JPU XVIII/93, sub Imbricaria tiliacea).

Peltigera didactyla (With.) J. R. Laundon - Pécs: Magyarürög, Jakab-hegy. Substr.: terra arg. Leg. Fóriss F., 1955.07.05. (JPU 27578 (D), sub P. lepidophora; JPU 27587 (D), sub P. hazslinszkyi).

Peltigera horizontalis (Huds.) Baumg. - Pécs: Magyarürög, Jakab-hegy. Substr.: terra arg. Leg. Fóriss F., 1955.07.05. (JPU 27590 (D)).

Peltigera leucophlebia (Nyl.) Gyeln. - Pécs. Leg. Majer M., 1860. (JPU XVIII/77, sub P. aphthosa); Magyarürög, Jakab-hegy. Substr.: terra arg. musc. Leg. Fóriss F., 1955.07.05. (JPU 27716 (D), sub P. variolosa var. leucophlebia).

Peltigera polydactylon (Neck.) Hoffm. - Pécs: Magyarürög, Jakab-hegy. Substr.: terra arg. Leg. Fóriss F., 1955.07.05. (JPU 27591 (D)).

Peltigera praetextata (Sommerf.) Zopf - Hetvehely: a vasúti alagút mellett. É.sz.: 46,125852 ${ }^{\circ}$, K.h.: 18,032723․ Substr.: saxa calc. musc. Leg. Kovács D., 2015.03.08. (JPU 32109). - Pécs. Leg. Majer M., 1860. (JPU XVIII/78, sub P. canina).

Peltigera rufescens (Weiss) Humb. - Pécs. Leg. Majer M., 1860. (JPU XVIII/79).

Pertusaria albescens (Huds.) M. Choisy et Werner - Kővágószőlős: Jakab-hegy, Zsongor-kő alatt. É.sz.: 46,091992 ${ }^{\circ}$ K.h.: 18,139564. Substr.: cort. Querci. Leg. Kovács D., 2014.10.18. (JPU 32085). - Pécs. Leg. Majer M., 1860. (JPU XVIII/98, sub P. communis var. variolosa); Dömörkapu. É.sz.: 46,097735 ${ }^{\circ}$ K.h.: 18,229966 ${ }^{\circ}$ Substr.: cort. Querci. Leg. Kovács D., 2014.10.03. (JPU 32074); Dömörkapu. Substr.: cort. Querci. Leg. Fóriss F., 1955.07.02. (JPU 27360, sub P. henrici); Kis-Tubes, kilátó. É.sz.: 46,102908, K.h.: 18,207917² Substr.: cort. Querci. Leg. Kovács D., 2015.03.20 (JPU 32101); Középdeindol-Hegyhát út. É.sz.: 46,103859, K.h.: 18,194559. Substr.: cort. Querci. Leg. Kovács D., 2015.02.21. (JPU 32012); Közép-Daindoltól É-ra, Lapisi út mellett. É.sz.: 46,103782º K.h.: 18,201149². Substr.: cort. Querci. Leg. Kovács D., 2015.03.20. (JPU 32102); Közép-Daindoltól É-ra. É.sz.: 46,099872 ${ }^{\circ}$ K.h.: 18,201679. Substr.: cort. Querci. Leg. Kovács D., 2015.03.20. (JPU 32118); Inter Dömörkapu et Irma út. Substr.: cort. Querci. Leg. Fóriss F., 1955.07.03. (JPU 27367 (D), sub P. discoidea); Inter Dömörkapu et Irma út. Substr.: cort. Querci. Leg. Fóriss F., 1955.07.01. (JPU 27368 (D), sub P. henrici) [FóRISS 1957]; Magyarürög, Jakab-hegy. Substr.: cort. Querci et Fagi. Leg. Fóriss F., 1955.07.05. (JPU 27609, sub P. globulifera f. elaeizans; JPU 27611 (D), sub P. discoidea; JPU 27713, sub P. globulifera f. nigrescens; JPU 27639 (D), sub P. globulifera f. elaeizans).

Pertusaria amara (Ach.) Nyl. - Kővágószőlős: Jakab-hegy, Sasfészektől ÉNy-ra. É.sz.: 46,09607 , K.h.: 18,12985 ${ }^{\circ}$ Substr.: cort. Querci. Leg. Kovács D., 2014.11.07. (JPU 32067); Jakab-hegy, Zsongor-kő alatt. É.sz.: 46,091992º K.h.: 18,139564º́s É.sz.: 46,091795 ${ }^{\circ}$ K.h.: 18,139671 . Substr.: cort. Querci. Leg. Kovács D., 2014.10.18 (JPU 32085), 2014.11.25. (JPU 32048).

Pertusaria leucosora Nyl. - Kővágószőlős: Jakab-hegyi kilátó. Substr.: saxa aren. Leg. Fóriss F., 1955.07.05. (JPU 27698 (D), sub var. microsora). [FóRISS 1957].

Phaeophyscia orbicularis (Neck.) Moberg - Hetvehely: a vasúti alagút mellett. É.sz.: 46,125852 ${ }^{\circ}$, K.h.: 18,032723․ Substr.: cort. Fraxini orni. Leg. Kovács D., 2015.03.08. (JPU 32139).

Phlyctis argena (Ach.) Flot. - Abaliget: vasútállomás. É.sz.: 46,150390, K.h.: 18, 078109 és É.sz.: 46,154068 ${ }^{\circ}$, K.h.: 18,077888 Substr.: cort. Carpini et Acer pseudoplatanus. Leg. 
Kovács D., 2014.12.19. (JPU 32016; JPU 32021; JPU 32022). - Kővágószőlős: Jakab-hegy, Sasfészektól ÉNy-ra. É.sz.: 46,09607 , K.h.: 18,12985 Substr.: cort. Querci. Leg. Kovács D., 2014.11.07. (JPU 32063); Jakab-hegy Zsongor-kő alatt. É.sz.: 46,091486º, K.h.: 18,139943². Substr.: putr. Leg. Kovács D., 2014.11.25. (JPU 32047). - Pécs: Közép-Daindoltól É-ra. É.sz.:

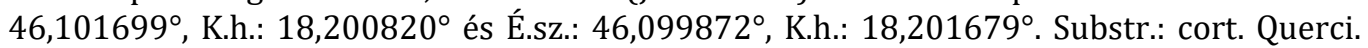
Leg. Kovács D., 2015.03.20. (JPU 32091; JPU 32128); Pécs-Vasas, Kopasz-óvár. É.sz.: 46,141188, K.h.: 18,311531․ Substr.: cort. Querci. Leg. Kovács D., 2015.04.02. (JPU 32134); Vidámpark. É.sz.: 46,099645 ${ }^{\circ}$ K.h.: 18,231337 . Substr.: cort. Querci. Leg. Kovács D., 2014.10.03. (JPU 32070). - Püspökszentlászló: Arborétum mellett. É.sz.: 46,189619², K.h.: 18,365523․ Substr.: cort. Pyri. Leg. Kovács D., 2015.03.28. (JPU 32136). - Mecsek: Zengő. Substr.: cort Querci. Leg. Balanyi L., 1961.05.22. (JPU 31448).

Physcia adscendens (Fr.) H. Olivier - Abaliget: vasútállomás, a lucosban. É.sz.: 46,151883', K.h.: 18,078331․ Substr.: cort. Robinia pseud. Leg. Kovács D., 2014.12.19. (JPU 32017). Pécs: Misina. Substr.: cort. Laricis. Leg. Fóriss F., 1955.07.03. (JPU 27423).

Physcia aipolia (Humb.) Fürnr. - Pécs: Magyarürög, in vinetis. Substr.: cort. Juglandis. Leg. Fóriss F., 1955.07.05. (JPU 27535; JPU 27536 (D), sub f. caesiopruinosa); Magyarürög, Jakab-hegy. Substr.: cort. Juglandis. Leg. Fóriss F., 1955.07.05. (JPU 27632).

Physcia stellaris (L.) Nyl. - Pécs. Leg. Majer M., 1860. (JPU XVIII/88, sub Parmelia s.); Magyarürög, Jakab-hegy. Substr.: cort. Juglandis. Leg. Fóriss F., 1955.07.05. (JPU 27633, sub var. radiata).

Physconia distorta (With.) J. R. Laundon - Pécs. Leg. Majer M., 1860. (JPU XVIII/87, sub Parmelia pulverulenta); Magyarürög, Jakab-hegy. Substr.: cort. Juglandis. Leg. Fóriss F., 1955.07.05. (JPU 27638, sub Physcia pulverulenta var. allochroa).

Physconia enteroxantha (Nyl.) Poelt - Abaliget: vasútállomás. É.sz.: 46,156156º K.h.: 18,073849 ${ }^{\circ}$. Substr.: corticem. Leg. Kovács D., 2014.12.19. (JPU 32054). - Pécs: KözépDaindoltól É-ra. É.sz.: 46,099872 , K.h.: 18,201679º és É.sz.: 46,100194 K.h.: 18,201729. Substr.: cort. Querci et Fraxini orni. Leg. Kovács D., 2015.03.20. (JPU 32130; JPU 32131); Magyarürög, Jakab-hegy. Substr.: cort. Tiliae. Leg. Fóriss F., 1955.07.05. (JPU 27615 (D), sub Physcia leucoleiptes var. enteroxanthella); Misina. Substr.: cort. Querci cerris. Leg. Fóriss F., 1955.07.03. (JPU 27418, sub Physcia leucoleiptes); Tubes, Lapisi út. É.sz.: 46,103782º K.h.: 18,201149 . Substr.: cort. Querci. Leg. Kovács D., 2015.03.20. (JPU 32103).

Placynthiella icmalea (Ach.) Coppins et P. James - Kővágószőlős: Jakab-hegy, Zsongor-kő alatt. É.sz.: 46,091881 ${ }^{\circ}$ K.h.: 18,138325ํ. Substr.: putr. Leg. Kovács D., 2014.04.12. (JPU 32086).

Placynthium nigrum (Huds.) Gray - Pécs: Irma út, Lenkei pihenő. Substr.: saxa calc. Leg. Fóriss F., 1955.07.02. (JPU 27393, sub f. densatum); Kis-Tubes, kilátó. É.sz.: 46,102908, K.h.: 18,207914․ Substr.: saxa dolom. Leg. Kovács D., 2015.03.20. (JPU 32110); Tubes, Lapisi út. É.sz.: 46,104081 ${ }^{\circ}$ K.h.: 18,201145․ Substr.: saxa calc. Leg. Kovács D., 2015.03.20. (JPU 32132).

Platismatia glauca (L.) W. L. Culb. et C. F. Culb. - Kővágószőlős: Jakab-hegy, Zsongor-kő alatt. É.sz.: 46,092133 ${ }^{\circ}$ K.h.: 18,137602 ${ }^{\circ}$ Substr.: cort. Querci. Leg. Kovács D., 2014.11.07. (JPU 32059).

*Pleurosticta acetabulum (Neck.) Elix et Lumbsch - Pécs: Misina. Substr.: cort. Laricis. Leg. Fóriss F., 1955.07.03. (JPU 27437, sub Parmelia a. f. carneola).

Porpidia crustulata (Ach.) Hertel et Knoph - Pécs: Farkas-forrástól D-re. É.sz.: 46,096516², K.h.: 18,163714 . Substr.: saxa aren. Leg. Kovács D., 2014.09.07. (JPU 32071); Magyarürög, Jakab-hegy. Substr.: saxa aren. Leg. Fóriss F., 1955.07.05. (JPU 27595, sub Lecidea c. f. subconcentrica); Misina. Substr.: saxa aren. Leg. Fóriss F., 1955.07.03. (JPU 27483, sub Lecidea c.). 
Protoparmeliopsis muralis (Schreb.) M. Choisy - Pécs: Dömörkapu. Substr.: saxa calc. Leg. Fóriss F., 1955.07.02. (JPU 27364, sub Squamaria m. var. muralis); Kis-Tubes, kilátó. É.sz.: 46,102908 ${ }^{\circ}$ K.h.: 18,207914․ Substr.: saxa dolom. Leg. Kovács D., 2015.03.20. (JPU 32111). *Pseudevernia furfuracea (L.) Zopf var. ceratea (Ach.) D. Hawksw. - Pécs: Éger-völgy. É.sz.: 46,091535, K.h.: 18,178371 . Substr.: putr. Querci. Leg. Kovács D., 2015.03.07. (JPU 32120).

*Psilolechia lucida (Ach.) M. Choisy - Kővágószőlős: Jakab-hegy, Sasfészektől K-re. É.sz.: 46,092133'ㅐ. K.h.: 18,137602. Substr.: saxa aren. Leg. Kovács D., 2014.11.07. (JPU 32043); Jakab-hegy, Zsongor-kő alatt. É.sz.: 46,091992 , K.h.: 18,139564º. Substr.: saxa aren. Leg. Kovács D., 2014.10.18. (JPU 32069).

Punctelia subrudecta (Nyl.) Krog - Abaliget: vasútállomás. É.sz.: 46,156156², K.h.: 18,073849․ Substr.: cort. Querci. Leg. Kovács D., 2014.12.19. (JPU 32041).

*Pycnothelia papillaria (Ehrh.) L. M. Dufour - Cserkút: a falu K-i határán, turista ösvény mellett. É.sz.: 46,072259, K.h.: 18,142539. Substr.: terra. Leg. Csiky J., 2014.11.28. (JPU 32146). - Pécs: Pécs-Vasas, Kopasz-óvár. É.sz.: 46,141188, K.h.: 18,311531. Substr.: terra arg. Leg. Kovács D., 2015.04.02. (JPU 32049).

Ramalina farinacea (L.) Ach. - Abaliget: vasútállomás, a lucosban. É.sz.: 46,151883 ${ }^{\circ}$ K.h.: 18,078331․ Substr.: cort. Robinia pseud. Leg. Kovács D., 2014.12.19. (JPU 32018).

Ramalina fraxinea (L.) Ach. - Pécs. Leg. Majer M., 1860. (JPU XVIII/81).

Rhizocarpon geographicum (L.) DC. - Kővágószőlős: Babás-szerkövek. É.sz.: 46,092209², K.h.: 18,129004 . Substr.: saxa aren. Leg. Kovács D., 2014.11.07. (JPU 32044).

Rhizocarpon hochstetteri (Körb.) Vain. - Pécs: Magyarürög, Jakab-hegy. Substr.: saxa aren. Leg. Fóriss F., 1955.07.05. (JPU 27711 (D), sub Catocarpon h.).

Rinodina albana (A. Massal.) A. Massal. - Pécs: Misina. Substr.: cort. Querci. Leg. Fóriss F., 1955.07.03. (JPU 27406 (D)).

Rinodina oxydata (A. Massal.) A. Massal. - Pécs: Misina, Substr.: saxa aren. Leg. Fóriss F., 1955.07.03. (JPU 27481, sub R. discolor).

*Rinodina sophodes (Ach.) A. Massal. - Pécs: Dömörkapu. Substr.: cort. Fraxini. Leg. Fóriss F., 1955.07.02. (JPU 27331).

Rinodinella controversa (A. Massal.) H. Mayrhofer et Poelt - Pécs: Dömörkapu. Substr.: saxa calc. Leg. Fóriss F., 1955.07.03. (JPU 27345 (D), sub Rinodina crustulata).

Romjularia lurida (Ach.) Timdal - Pécs: Kis-Tubes, kilátó. É.sz.: 46,102908, K.h.: 18,207914․ Substr.: saxa dolom. Leg. Kovács D., 2015.03.20. (JPU 32117); Tubes, Lapisi út. É.sz.: 46,103782 ${ }^{\circ}$ K.h.: 18,201149. Substr.: saxa dolom. Leg. Kovács D., 2015.03.20. (JPU 32094).

Sarcogyne regularis Körb. - Pécs: Dömörkapu. Substr.: saxa calc. Leg. Fóriss F., 1955.07.01. (JPU 27342 (D), sub Biatorella pruinosa f. intermedia).

Scoliciosporum chlorococcum (Graewe ex Stenh.) Vězda - Abaliget: vasútállomás. É.sz.: 46,155479 ${ }^{\circ}$ K.h.: 18,075057. Substr.: cort. Pinus. Leg. Kovács D., 2014.12.19. (JPU 32078).

Strangospora moriformis (Ach.) Stein - Pécs: Magyarürög, Jakab-hegy. Substr.: lign. sicc. Querci. Leg. Fóriss F., 1955.07.05. (JPU 27662 (D), sub Biatorella m.); Misina. Substr.: lign. sicc. Querci. Leg. Fóriss F., 1955.07.03. (JPU 27441, sub Biatorella m.).

Synalissa symphorea (Ach.) Nyl. - Pécs: Kis-Tubes, kilátó. É.sz.: 46,102908, K.h.: 18,207914․ Substr.: saxa dolom. Leg. Kovács D., 2015.03.20. (JPU 32089); Tubes, Lapisi út. É.sz.: 46,103782 ${ }^{\circ}$ K.h.: 18,201149. Substr.: saxa dolom. Leg. Kovács D., 2015.03.20 (JPU 32096).

*Tomasellia arthonioides (A. Massal.) A. Massal. - Pécs: Dömörkapu. Substr.: cort. Fraxini orni. Leg. Fóriss F., 1955.07.02. (JPU 27330).

*Toninia candida (Weber) Th. Fr. - Pécs. Leg. Majer M., 1860. (JPU XVIII/103, sub Lecidea candida). 
Trapelia coarctata (Turner) M. Choisy - Pécs: Magyarürög, Jakab-hegy. Substr.: saxa aren. Leg. Fóriss F., 1955.07.05. (JPU 27701, sub Lecidea goniophila f. pungens).

*Trapelia involuta (Taylor) Hertel - Pécs: Magyarürög, Jakab-hegy. Substr.: saxa aren. Leg. Fóriss F., 1955.07.05. (JPU 27573, sub Biatora coarctata var. elachista).

Trapeliopsis flexuosa (Fr.) Coppins et P. James - Abaliget: vasútállomás. É.sz.: 46,155479º,

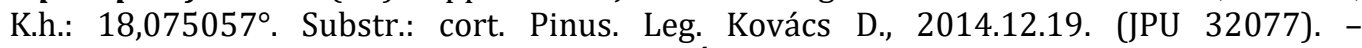
Kővágószőlős: Jakab-hegy, Zsongor-kő alatt. É.sz.: 46,091881, K.h.: 18,138325․ Substr.: putr. Leg. Kovács D., 2014.04.12. (JPU 32086).

*Varicellaria hemisphaerica (Flörke) I. Schmitt et Lumbsch - Kővágószőlős: Zsongor-kő alatt. É.sz.: 46,090436 K.h.: 18,142055². Substr.: cort. Querci. Leg. Kovács D., 2014.04.12. (JPU 32073).

*Verrucaria marmorea (Scop.) Arnold - Pécs: Kis-Tubes, kilátó. É.sz.: 46,102908º K.h.: 18,207914․ Substr.: saxa dolom. Leg. Kovács D., 2015.03.20. (JPU 32129).

*Verrucaria nigrescens Pers. - Pécs: Dömörkapu. Substr.: saxa calc. Leg. Fóriss F., 1955.07.01. (JPU 27365, sub var. subcontinua); Kis-Tubes, kilátó. É.sz.: 46,102908º K.h.: 18,207914․ Substr.: saxa dolom. Leg. Kovács D., 2015.03.20. (JPU 32088; JPU 32093).

*Verrucaria parmigera J. Steiner - Pécs: Kis-Tubes, kilátó. É.sz.: 46,102908, K.h.: 18,207914․ Substr.: saxa dolom. Leg. Kovács D., 2015.03.20. (JPU 32093).

*Xanthoparmelia conspersa (Ach.) Hale - Pécs. Leg. Majer M., 1860. (JPU XVIII/89, sub Imbricaria ceratophylla; JPU XVIII/91, sub Imbricaria conspersa).

*Xanthoparmelia verruculifera (Nyl.) O. Blanco, A. Crespo, Elix, D. Hawksw. et Lumbsch Pécs: Magyarürög, Jakab-hegy. Substr.: cort. Aesculi. Leg. Fóriss F., 1955.07.05. (JPU 27626, sub Parmelia v. var. conspurcata).

\section{Revízióra, megerősítésre váró fajok}

Collema sp. - Pécs. Leg. Majer M., 1860. (JPU XVIII/101, sub Leptogium tremelloides). Pontosabb határozáshoz a példány nem elég fejlett.

Lecania erysibe (Ach.) Mudd - Pécs: Mecsek szálló. Substr.: saxa calc. Leg. Fóriss F., 1955.07.06. (JPU 27758, sub var. rabenhorstii). - További taxonómiai tisztázást igényel.

\section{Megvitatás}

Jelen munkánkban 115 taxon 221 előfordulási adatát adjuk közre a Mecsek területéről (545 $\mathrm{km}^{2}$ ). Összesen 22 faj bizonyult újnak a hegységre nézve. Közülük nyolc taxon esetében csak régebbi herbáriumi adatokkal rendelkezünk (például Toninia candida), míg 14 fajnak (például Catapyrenium rufescens, Psilolechia lucida) vannak aktuálisan gyüjtött mintái is. Ezekkel együtt 213 tagúra bővült a Mecsek zuzmófajlistája. Ez a szám azonban továbbra is jelentősen elmarad a hegység becsült fajdiverzitásától (kb. 400 faj) (LőKös 2010), így a feltáró munka folytatása mindenképpen indokolt. Kimutatásra került a terjedőben lévő Dimerella pineti savanyú talajról, a ritka Varicellaria hemisphaerica, az Ochrolechia arborea negyedik hazai publikált adata és a Pycnothelia papillaria két új lelőhelye is.

\section{Köszönetnyilvánítás}

Köszönettel tartozunk Csiky Jánosnak és Deme Juditnak értékes adataik átadásáért. Külön köszönet illeti Csiky Jánost, a JPU kurátorát a herbáriumi anyag rendelkezésünkre bocsátásáért és a kézirathoz fúzött megjegyzéseiért, Matus Gábort pedig az alapos lektorálásért. 


\section{Irodalomjegyzék}

CABI (2015): The Index Fungorum. - The Index Fungorum Partnership, http://www.indexfungorum.org. (Hozzáférés: 2015.09.16.)

FARKAS E. \& LőKÖs L. (2009): Zuzmók biodiverzitás-vizsgálata Gyürüfü környékén. (Biodiversity studies on lichen-forming fungi at Gyűrüfü (SW Hungary). - Mikológiai Közlemények, Clusiana 48 (2): 145-153.

FARKAS E., LőKÖS L. \& MOLNÁR K. (2009): Az Ochrolechia arborea zuzmófaj megjelenése Magyarországon. - Mikológiai Közlemények, Clusiana 48 (1): 19-24.

FóRISS F. (1957): Új zuzmófajok és fajváltozatok Magyarország flórájában. (Neue Flechtenarten und Varietäten in der Flora Ungarns). - Botanikai Közlemények 47 (1-2): 67-76.

GALLÉ L. (1978): Adatok a Barcsi Ősborókás zuzmóvegetációjának ismeretéhez. (Daten zu den Kenntnis der Flechtenvegetation des Barcser Wacholder Naturschutzkreises). - Dunántúli Dolgozatok (A) Természettudományi Sorozat 1: 45-50.

KovÁcs D. (2015): A pécsi egyetemi herbárium (JPU) zuzmógyűjteményeinek digitális adatbázisa. - In: SZỨcS P. \& PÉNZESNÉ KóNYA E. (szerk.), III. Aktuális eredmények a kriptogám növények kutatásában, 2015. november 17-18., A konferencia előadásainak és posztereinek összefoglalói. Eger, p. 40.

LőKös L. (2000): The lichen flora of the Villány Mts. - Dunántúli Dolgozatok (A) Természettudományi Sorozat 10: 13-35.

LőKös L. (2010): A Mecsek zuzmóflórája. - Dunántúli Dolgozatok (A) Természettudományi Sorozat 12: 20-41.

MARSTALLER R. (1993): Die Moosgesellschaften des Villányer Gebirges in Südungarn. - Phytocoenologia 22 (2): 193-273.

MVhT (2013): Mecsek, Villányi-hegység: turistatérkép, 1:40 000. - Cartographia Kft., Budapest, ISBN 978-963-353-132-7

THоR G. (1988): Some lichens from Hungary. - Graphis Scripta 2: 69-71.

VARGA N., FARKAS E. \& LŐKÖS L. (2014): A Cserkúti dombsor (Nyugat-Mecsek) zuzmói és zuzmólakó mikrogombái. - In: Schmidt D., KovÁcs M. \& BARTHA D. (szerk.), X. Aktuális Flóra- és Vegetációkutatás a Kárpát-medencében nemzetközi konferencia absztraktkötete. Nyugat-magyarországi Egyetem Kiadó, Sopron, p. 228.

VERSEGHY K. (1973): A Villányi-hegység zuzmóvegetációja. (Die Flechtenvegetation des Villányer Gebirges). - Botanikai Közlemények 60 (3): 157-162.

VERSEGHY K. (1994): Magyarország zuzmóflórájának kézikönyve. (The lichen flora of Hungary). - Magyar Természettudományi Múzeum, Budapest, 415 pp.

Beérkezett / received: 2016. 03. 30. • Elfogadva / accepted: 2016. 05. 14. 